Orear is mistaken to claim that silence implies acquiescence. Often it means just busyness. By the same test, it is mistaken of Dr Schwartz to think that the agreement of one per cent of the membership of a society is a sufficient mandate for new undertakings. Ninetynine per cent would be a better figure from which to open negotiations. But with that reservation, there is no need artificially to restrict the scope which learned societies should choose for themselves. If they wish to become pressure groups, there is no reason why they should deny themselves that luxury, and it is, of course, delightfully disingenuous that Dr Edward Teller, who has been a one-man pressure group on defence policy for several years, should now maintain that pressure groups are a nuisance. Where societies are concerned, what matters is what most members want.

There remains the question of how physicists in the United States should set out to tackle the kinds of questions which Dr Schwartz would like to raise within the American Physical Society. The first thing is that if there is a group of physicists which feels a need to take a special interest in public issues, and if it considers that it has something special to contribute, there is no reason why it should not form a society specifically for that purpose. In time it might even establish a reputation for responsibility and good sense.

\section{Fast Reactors in Europe}

The European Nuclear Energy Agency celebrated its tenth anniversary in Paris last week with the cheerful announcement of a plan to investigate the building of a fast reactor as a joint project. It has been decided to set up two working parties-one technical, one more directly industrial- on fast reactors. The formation of the technical group was prompted by the uneasy feeling that fast reactors have so far been developed on too narrow a front. Hitherto it has been assumed that the best method of cooling is by pumping liquid sodium around the reactor. At the back of people's minds has been the feeling that perhaps gas or steam would do the job equally well. Although those who have invested in fast reactor development already, including the UK Atomic Energy Authority, have presumably satisfied themselves on the point, the delegates at the recent meeting in Paris saw no harm in making doubly sure. The working group will therefore be making a technical study of the two systems, and comparing them with sodium cooling. The group will report back in June, and if there then seems a need to go ahead and produce some hardware, this could be set in motion by the end of the year. Much will, of course, depend on the reaction of individual countries to the report.

The other working party has been set up with the intention of taking early industrial soundings about possible fast reactor projects. Its aim is to devise ways in which any joint reactor development undertaken by ENEA could be smoothly handed over to industry when it is complete. One delegate at the ENEA meeting described the formation of this group as one of the fruits of the Dragon project. Dragon is coming to an end without as much industrial follow-up as some people consider it deserves. Happily, there are some signs of interest; five European companies have joined forces to consider the formation of a European organization to promote the sales of reactors using Dragon high temperature technology. The companies are the Nuclear Power Group (UK), Belgonucléaire (Belgium), Gutehoffnungshutte (West Germany), SNAM Projetti S.p.A. (Italy) and Groupement Atomique Alsacienne Atlantique (France). This is an encouraging sign of international interest in the system. At the same time, ENEA has set up a committee whose task it will be to press forward the commercial application of heavy water reactors in Europe. Although almost every conceivable variety of heavy water moderated reactor has been designed-and a number have been built-electricity utilities have tended to fight shy of them. The new group will attempt to break through this consumer resistance, fortified perhaps by the knowledge that the British example of the breed, the steam generating heavy water reactor at Winfrith, reached its full design capability of $100 \mathrm{MW}$ late last month. The UKAEA, which designed and built the SGHWR, has its own ideas about selling it, and has prepared a contract in collaboration with Finnish industry to supply an SGHWR to Imatran Voima Oy, the Finnish electricity utility.

\section{Money for British Postgraduates}

THE Department of Education and Science is thinking of transferring all responsibility for postgraduate awards to central government. Consultations are in progress with the Committee of Vice-Chancellors and Principals, the Association of University Teachers, the Association of Principals of Technical Institutions, the Association of Teachers in Technical Institutions, the National Union of Students and the National Society of Art Education.

At present these awards are made by various departments, including the Department of Education and Science and the Scottish Education Department, as well as by research councils and local education authorities in England and Wales. Although local education authorities can, in fact, make awards in any field-even to cover research leading to a doctorate of philosophy-the awards are usually provided to cover vocational courses such as diplomas in management studies, or for polytechnic courses. These awards are financially similar to the ones provided for first degree courses and are assessed according to parental income.

The Secretary of State for Education and Science, Mr Patrick Gordon Walker, has told local authorities that the present division of responsibility is causing increasing difficulty to applicants, academic authorities and award-making bodies. In 1966, at the annual conference of the Association of Education Committees, a resolution was passed calling on the Department of Education and Science to assume full responsibility for awards for postgraduate study apart from those studies of a strictly vocational nature.

Mr. Gordon Walker adds that this proposal is not concerned with the total number of postgraduate awards made from public funds but simply with "the most efficient and economical way of administering them". He further maintains that until the idea of central control is completely acceptable, there is no point in considering in detail the way in which this might be brought about. 